\title{
Case series: The McGrath® videolaryngoscope - an initial clinical evaluation
}

\author{
[Série de cas: Le vidéolaryngoscope McGrath® - une première évaluation \\ clinique]
}

Ben Shippey BmbS MrCP FRCA, David Ray MD FRCA, Dermot McKeown Mbchb FRCA

Purpose: To document tracheal intubation success rates and airway instrumentation times using the newly designed McGrath ${ }^{\circledR}$ videolaryngoscope.

Methods: We prospectively recorded factors associated with difficult tracheal intubation, factors causing actual difficulty in tracheal intubation, as well as complications arising from use of the new McGrath ${ }^{\circledR}$ videolaryngoscope in a series of adult patients with normal preoperative airway examinations. All patients were undergoing scheduled or elective surgery. In the first 75 patients (phase I), experience with airway instrumentation was documented, while in the second 75 patients (phase II), the time required to obtain an optimal view of the larynx was recorded, as well as the time to complete tracheal intubation.

Results: Ninety-eight percent of all tracheal intubations were successful using the McGrath ${ }^{\circledR}$ videolaryngoscope. Cormack and Lehane grade I views were obtained in I43 patients (95\%) and grade II views were achieved in six (4\%). In phase II, the median time required to obtain an adequate view was $6.3 \mathrm{sec}$ [interquartile range 4.7-8.7 (range 2-26.3)], and to complete tracheal intubation was $24.7 \mathrm{sec}$ [18.5-34.4 (I I.4-286)]. Fortynine $(65 \%)$ of the tracheal intubations were completed within $30 \mathrm{sec}$, and 72 (96\%) were completed within one minute. No complications were encountered in any patient.

Conclusions: The McGrath ${ }^{\circledR}$ videolaryngoscope is an effective aid to airway management in patients with normal airways, based upon intubation success rates and the ability to rapidly secure the airway. Its potential advantages of convenience and portability warrant further evaluation in comparison with other airway devices and in patients with difficult airways.

CAN J ANESTH 2007 / 54: 4 / pp 307-313
Objectif : Documenter les taux de réussite d'intubation trachéale et les temps d'instrumentation des voies aériennes pour le nouveau vidéolaryngoscope McGrath ${ }^{\circledR}$.

Méthode: Nous avons enregistré, de façon prospective, les facteurs associés à une intubation trachéale difficile, ceux causant une difficulté réelle de l'intubation trachéale ainsi que les complications dues à l'utilisation du nouveau vidéolaryngoscope McGrath ${ }^{\circledR}$ chez une série de patients adultes présentant une anatomie des voies aériennes normales avant l'opération. Tous les patients devaient subir une chirurgie élective. Nous avons documenté notre expérience de prise en charge des voies aériennes chez les 75 premiers patients (Phase I) et, chez les 75 autres patients (Phase II), nous avons mesuré le temps requis jusqu'à obtention d'une visualisation optimale du larynx ainsi que le temps jusqu'à l'intubation trachéale complète.

Résultats : Le taux de réussite des intubations trachéales pratiquées à l'aide du vidéolaryngoscope McGrath ${ }^{\circledR}$ a été de $98 \%$. Nous avons obtenu une visualisation de type I sur l'échelle de Cormack et Lehane chez 143 patients (95\%) et de type II chez six patients (4\%). Pendant la phase II, le temps moyen requis pour obtenir une visualisation adéquate était de 6,3 sec [écart interquartile 4,7-8,7 (écart 2-26,3)], et de 24,7 sec avant intubation trachéale complète [18,5-34,4 (II,4-286)]. On a effectué 49 (65 $\%)$ intubations trachéales en $30 \mathrm{sec}$ ou moins, et 72 (96\%) en une minute ou moins. II n'y a eu aucune complication.

Conclusion : Le vidéolaryngoscope McGrath ${ }^{\circledR}$ est un outil efficace pour la prise en charge des voies aériennes chez des patients avec une anatomie normale, si l'on se base sur les taux de réussite d'intubation et la capacité de sécuriser rapidement les voies aériennes. Sa facilité d'utilisation et sa portabilité justifient une évaluation plus poussée, incluant une comparaison avec d'autres dispositifs semblables et une utilisation chez des patients présentant des difficultés d'intubation.

From the Department of Anesthesia, Critical Care and Pain Medicine, Royal Infirmary of Edinburgh, Edinburgh, Scotland.

Address correspondence to: Dr. Ben Shippey, Department of Anesthesia, Critical Care and Pain Medicine, Royal Infirmary of Edinburgh, 51 Little France Crescent, Edinburgh EH16 4SA, Scotland. Phone: +441312423224; E-mail: benshippey@mac.com

Competing interests: All three investigators have assisted Aircraft Medical in the development of the McGrath ${ }^{\circledR}$ videolaryngoscope. The employing authority of the investigators has received payment from Aircraft Medical for professional advice given by Drs. McKeown and

Ray on a consultative basis. Disposable laryngoscope blades were provided free of charge by Aircraft Medical for this clinical evaluation.

Accepted for publication October 24, 2006.

Revision accepted December 12, 2006.

Final revision accepted December 22, 2006. 
$\mathrm{V}$

IDEOLARYNGOSCOPY is becoming a widely accepted airway management technique. There are several potential advantages over direct laryngoscopy including better views of the larynx, ${ }^{1-3}$ particularly in patients with limited cervical spine motion, ${ }^{4,5}$ reduced tracheal intubation time, ${ }^{4}$ and educational value. ${ }^{6,7}$ Both experienced and inexperienced intubators find videolaryngoscopy easier and quicker than direct laryngoscopy in a difficult airway model..$^{8,9}$

Until recently, three videolaryngoscopes have been commercially available - the Glidescope ${ }^{\circledR}$ (Saturn Biomedical Inc, Burnaby, BC, Canada), the Macintosh VideoLaryngoscope (Karl Storz GmBH and Co., Tuttlingen, Germany) and the X-lite ${ }^{\circledR}$ (Rusch Inc., Tuttlingen, Germany). Use of the Glidescope ${ }^{\circledR}$ has been most extensively reported, ${ }^{1-5,8-22}$ and the Macintosh VideoLaryngoscope has been described recently. ${ }^{23}$ Successful use of the $\mathrm{X}$-lite ${ }^{\circledR}$ has also been reported ${ }^{24}$ but this device is no longer produced. All these videolaryngoscopes have limitations. For example, all require a separate screen and either a battery or power supply that limits their portability and facility of use, and all require the laryngoscope handle and/or blade to be sterilized between patients. Thompson has described a prototype laryngoscope blade and handle with a liquid crystal display ${ }^{25}$ but this system has never been produced commercially. A recent evaluation of the $\mathrm{CTrach}^{\mathrm{TM}}$, a variation on the intubating laryngeal mask airway incorporating a digital image of the larynx, found that initial views of the larynx were poor in $40 \%$ of patients. ${ }^{26}$

The McGrath ${ }^{\circledR}$ videolaryngoscope (Aircraft Medical, Edinburgh, UK) overcomes these problems. This new device, available since January 2006, is a self-contained instrument powered by a $1.5 \mathrm{v}$ (AA) battery contained within the handle; each battery provides more than $60 \mathrm{~min}$ of non-continuous use. The $33 \times 22.5 \mathrm{~mm}$, video graphics array $640 \times 480$ colour liquid crystal display (LCD) is mounted on the top of the laryngoscope handle, and tilts and swivels through a $90^{\circ}$ arc to allow optimal viewing (Figure 1 ).

The core of the blade is an adjustable length (by up to $34 \mathrm{~mm}$ ) "camera stick" with two hyperbright light emitting diodes (LEDs) and a small colour digital camera at the distal end. The light from the LEDs and the point of view from the camera are realigned anteriorly and to the left by lenses within a transparent acrylic single-use blade. The blade, which has a maximum depth of $12 \mathrm{~mm}$, covers the camera stick such that no part of the handle/camera stick assembly makes contact with the patient's mouth. The digital signal is processed within the camera stick and trans-

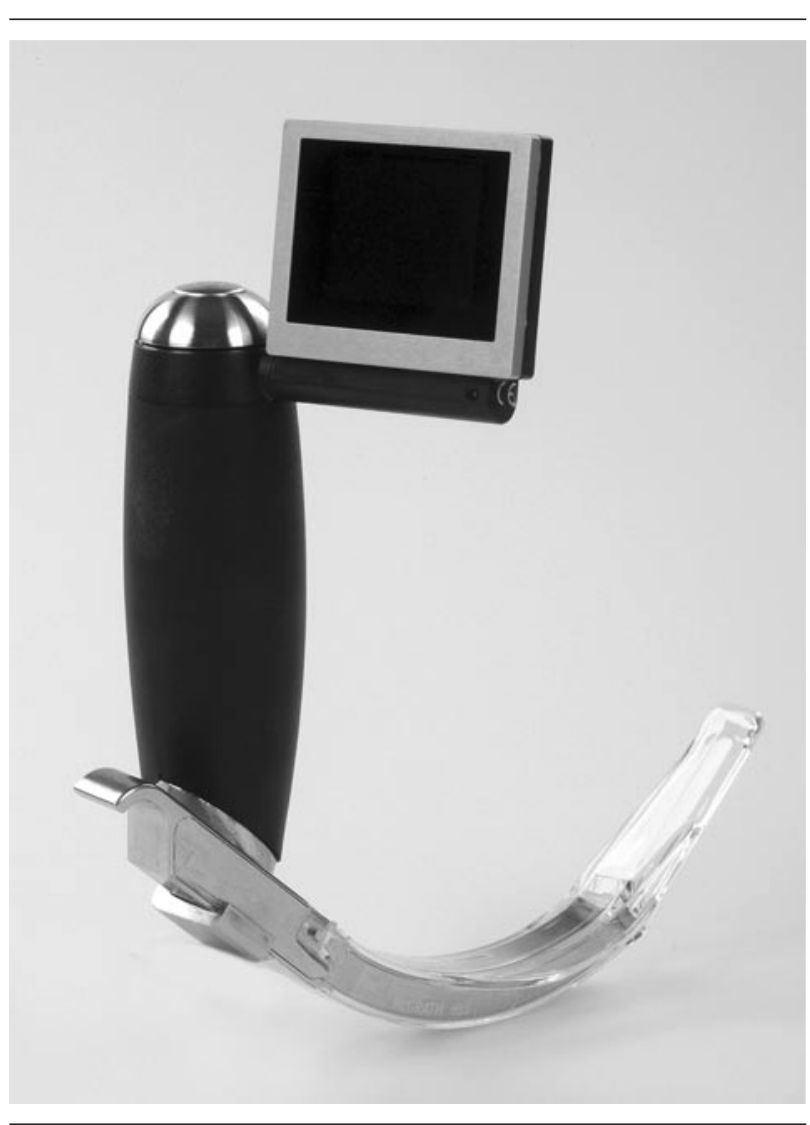

FIGURE 1 The McGrath ${ }^{\circledR}$ videolaryngoscope.

mitted to the screen (Figure 2) via contacts within the C-shaped clamp at the bottom of the handle. The handle and the camera stick can be disassembled easily for sterilization (Figure 3). As the device has limited reported use, we undertook an evaluation of the $\mathrm{McGrath}{ }^{\circledR}$ videolaryngoscope in a series of adult patients undergoing scheduled or elective surgery.

\section{Methods}

The need for ethical approval and patient consent were reviewed in detail with the local Research and Ethics Committee. As this clinical evaluation used a fully $\mathrm{CE}-$ marked $^{\mathrm{A}}$ product, a recognized technique, and did not involve any additional procedure for the

A CE marking is a declaration by the manufacturer that the product meets all the appropriate provisions of the relevant legislation implementing certain European Directives. CE marking gives companies easier access into the European market to sell their products without adaptation or rechecking. The initials "CE" do not stand for any specific words but are a declaration by the manufacturer that his product meets the requirements of the applicable European Directive(s). 

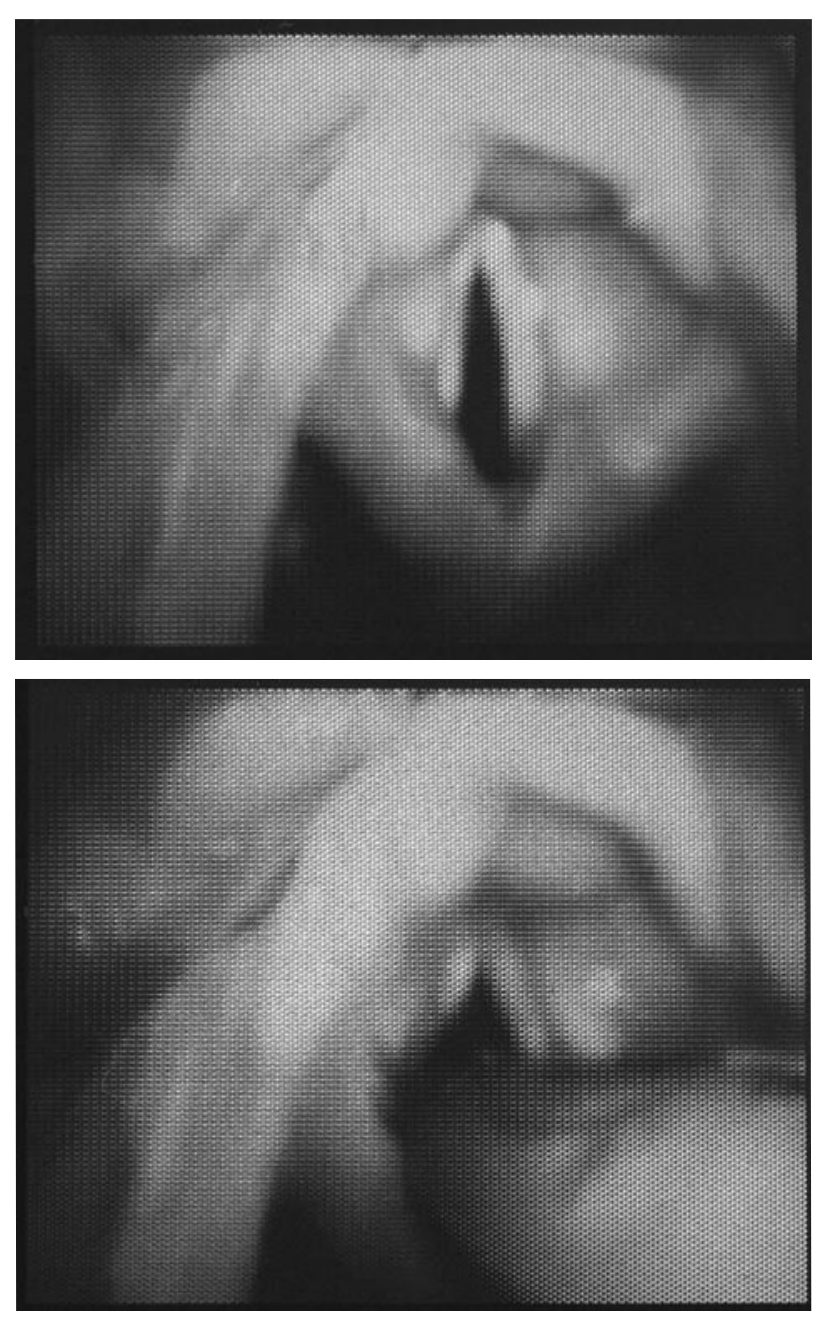

FIGURE 2 (a) View of larynx (grade I) and (b) view of tracheal tube insertion using the McGrath ${ }^{\circledR}$ videolaryngoscope.

patients, the committee deemed that formal approval and informed consent were not required.

Included in this evaluation were adult patients managed at the Royal Infirmary of Edinburgh who required general anesthesia, with muscle relaxation and tracheal intubation as part of their anesthetic technique. Patients were not excluded on the grounds of age, dentition or expected airway difficulty. Patients were mostly scheduled for laparoscopic gastrointestinal procedures such as cholecystectomy and hernia repair, thyroidectomy, and hepatobiliary procedures such as hepatic resection and pancreatic bypass. A smaller number of patients were scheduled for orthopedic or ophthalmic surgery. Patients with significant cardiorespiratory instability were excluded. Initially,

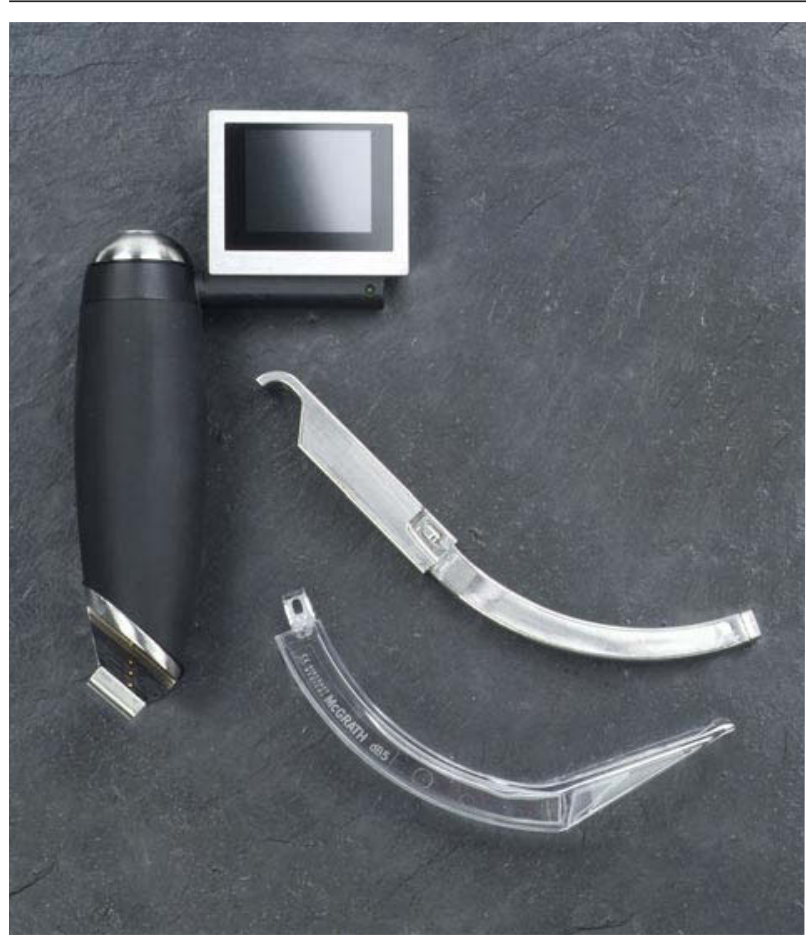

FIGURE 3 The McGrath ${ }^{\circledR}$ videolaryngoscope disassembled, showing the handle and liquid crystal display screen (left), "camera stick" (top right) and a single-use blade (bottom right).

patients who required rapid sequence induction of anesthesia were excluded, but as the experience and confidence of the investigators with the laryngoscope increased, these patients were included. Data were collected between January $26^{\text {th }}$ and April $5^{\text {th }} 2006$.

Patient age, gender, height and weight, and an assessment of the airway (Mallampati score, ${ }^{27}$ mouth opening, thyromental distance, neck movement, and dentition) were recorded. For each subject, airway intrumentation was performed by one of three anesthesiologists with more than seven (B.S.) and $>20$ (D.R., D.M.) years of clinical experience. Each had used an earlier model of the McGrath ${ }^{\circledR}$ videolaryngoscope in more than 20 intubations in airway manikins, however, none had experience with any McGrath ${ }^{\circledR}$ model in humans. The series was conducted in two phases. Phase I consisted of 75 patients in whom the laryngoscopy and tracheal intubation techniques were refined. The need for a stylet or bougie was assessed, and we identified that a stylet was mandatory for easy intubation. Phase II consisted of 75 patients for whom a stylet was used routinely. All three anesthesiologists 
were familiar with the use of the $\mathrm{McGrath}{ }^{\circledR}$ videolaryngoscope after ten tracheal intubations.

In the operating room, standard monitors were applied. Following insertion of a peripheral iv cannula and preoxygenation, anesthesia was induced with either propofol or thiopental followed by muscle paralysis according to the discretion of the attending anesthesiologist. The adjustable-length laryngoscope blade was set to the midpoint for all laryngoscopies. The McGrath ${ }^{\circledR}$ videolaryngoscope was inserted into the patient's mouth along the midline of the tongue, and the blade was advanced until the larynx became visible on the screen. The best laryngoscopic view obtained using the Cormack and Lehane classifica$\operatorname{tion}^{28}$ was recorded, as well as the number of attempts at laryngoscopy required to intubate the trachea with either a 8.0 - or $9.0-\mathrm{mm}$ internal diameter endotracheal tube (insertion and removal of the laryngoscope counted as one laryngoscopy). Adjuncts used to facilitate intubation were recorded, as well as any airway complications, including dental or soft tissue trauma, bleeding, episodes of hypoxia $\left(\mathrm{SpO}_{2}<92 \%\right)$ and/or equipment failure. If tracheal intubation with the McGrath ${ }^{\circledR}$ was unsuccessful within two attempts, or if $\mathrm{SpO}_{2}$ was $<92 \%$ before tracheal intubation was completed, a standard Macintosh laryngoscope was used.

In phase I (the first 75 consecutive patients) the operators refined their laryngoscopic technique. In phase II (the second 75 consecutive patients), the time required to obtain an optimal view of the larynx (time from inserting the laryngoscope past the teeth to the time an optimal view of the larynx appeared on the LCD screen) was recorded, as well as the time to complete tracheal intubation (from laryngoscope insertion to its removal from the patient's mouth after airway instrumentation). If tracheal intubation was difficult, or if the Macintosh laryngoscope blade was required, or whenever a complication arose, the event, surrounding circumstances, and any steps to overcome the problem were recorded.

\section{Results}

Data were collected from 150 patients who required tracheal intubation. Patient characteristics and the results of the preoperative airway assessment are shown in the Table. Tracheal intubation was successfully completed in 147 (98\%) patients using the McGrath ${ }^{\circledR}$ videolaryngoscope; 139 tracheal intubations were successful during initial laryngoscopy and eight were successful at the second laryngoscopy. Cormack and Lehane grade I views were obtained using the $\mathrm{McGrath}{ }^{\circledR}$ in 143 patients $(95 \%)$, grade II views in six patients (4\%), and in one patient no
TABLE Patient characteristics and airway assessment

\begin{tabular}{|c|c|}
\hline & All patients \\
\hline $\operatorname{Age}^{*}(\mathrm{yr})$ & $60 \pm 17.2$ \\
\hline Gender (male/female) & $66 / 84$ \\
\hline 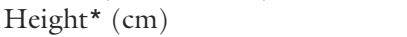 & $166 \pm 9.2$ \\
\hline Weight* $(\mathrm{kg})$ & $73.8 \pm 17.1$ \\
\hline Body mass index ${ }^{*}\left(\mathrm{~kg} \cdot \mathrm{m}^{-2}\right)$ & $26.8 \pm 6.0$ \\
\hline \multicolumn{2}{|l|}{ Mallampati score } \\
\hline 1 & $68(45 \%)$ \\
\hline 2 & $59(39 \%)$ \\
\hline 3 & $23(15 \%)$ \\
\hline Thyromental distance $<6.5 \mathrm{~cm}$ & $15(10 \%)$ \\
\hline Mouth opening $<3 \mathrm{~cm}$ & $4(3 \%)$ \\
\hline Reduced neck movement & $16(11 \%)$ \\
\hline Difficult dentition & $8(5 \%)$ \\
\hline \multicolumn{2}{|l|}{ Previous Cormack and Lehane grade } \\
\hline Unknown & $125(83 \%)$ \\
\hline I & $17(11 \%)$ \\
\hline II & $7(5 \%)$ \\
\hline III & $1(0.6 \%)$ \\
\hline
\end{tabular}

Values are mean $\pm \mathrm{SD},{ }^{*}$ or number of patients (\%).

view was obtained owing to an equipment failure of a pre-production device. A malleable stylet was used in 144 patients, and in two patients a gum elastic bougie facilitated tracheal intubation; tracheal intubation was accomplished in two patients using no adjunct. In two patients an initial attempt at tracheal intubation was made without a stylet, unsuccessfully. After subsequent mounting of the tracheal tube onto a stylet, airway instrumentation was successful in both cases.

For patients in phase II, the median time required to obtain the best Cormack and Lehane view was $6.3 \mathrm{sec}$ [interquartile range (IQR) 4.7-8.7 (range 2-26.3)]. The median time taken to complete tracheal intubation was $24.7 \mathrm{sec}$ [IQR 18.5-34.4 (range 11.4-286)]. Forty-nine of these intubations $(65 \%)$ were completed within $30 \mathrm{sec}$, and $72(96 \%)$ were completed in less than one minute. Twenty-four patients received rapid sequence induction of anesthesia. We obtained grade I laryngoscopic views in 23 of these patients (96\%) and accomplished tracheal intubation in all patients using the McGrath ${ }^{\circledR}$ at the first attempt. No patient developed regurgitation or aspiration of gastric contents.

Using the McGrath ${ }^{\circledR}$, tracheal intubation was rated as "easy" in 116 patients (79\%), "slightly difficult" in $25(17 \%)$, and "moderately difficult" in six (4\%). No intubations were rated as "very difficult". There was difficulty in passing the tracheal tube into the larynx in 14 patients, and in advancing the tube within the trachea in a further nine patients. Minor complications occurred in only four patients (3\%): oxygen saturation decreased below $92 \%$ in one patient, and a small 
amount of blood-stained secretion was observed in the oropharynx after removing the laryngoscope in three patients. Eighteen patients had at least two of six criteria associated with poor laryngoscopic views (body mass index $>35 \mathrm{~kg} \cdot \mathrm{m}^{-2}$, Mallampati score 3 or 4 , thyromental distance $<6.5 \mathrm{~cm}$, mouth opening $<3 \mathrm{~cm}$, previous Cormack and Lehane grade of III or more, or "difficult" dentition). ${ }^{29-31}$ A Cormack and Lehane grade I view was obtained in 16 of these patients, and a grade II view in the other two patients. Tracheal intubation was successful using the $\mathrm{McGrath}{ }^{\circledR}$ in all 18 patients, with first-time success achieved in 15 of these 18 patients. Tracheal intubation was "easy" in 11 patients, "slightly difficult" in five, and "moderately difficult" in two. There was some difficulty in obtaining a good laryngoscopic view in two patients; with repositioning, an improved view was achieved in both cases. In five patients there was difficulty related to insertion of the tracheal tube. There was no relationship between predictors of difficult laryngoscopy and tracheal intubation, and difficulty in using the McGrath ${ }^{\circledR}$ videolaryngoscope.

\section{Discussion}

The initial evaluation of the McGrath ${ }^{\circledR}$ videolaryngoscope in this case series demonstrates a high success rate of airway instrumentation in adult patients. Only three of the 150 evaluated patients required tracheal intubation using a standard Macintosh laryngoscope, and the complications were very minor and of low frequency. The median time taken to complete tracheal intubation with the McGrath ${ }^{\circledR}$ was $24.7 \mathrm{sec}$, and twothirds of tracheal intubations required less than 30 sec to complete. Ninety-six percent of timed tracheal intubations were completed in less than one minute.

These results are similar to those reported for other videolaryngoscopes and conventional laryngoscopes. ${ }^{2,4,9}$ It required longer than three minutes to complete tracheal intubation in two patients. One patient had undergone cervical fusion and had a Mallampati score of 3. At laryngoscopy a Cormack and Lehane grade II view was obtained, but the intubator had great difficulty in directing the tracheal tube into the larynx, eventually passing the tube over a gum elastic bougie. The other patient had previously undergone surgery to the floor of the mouth. Despite obtaining a Cormack and Lehane grade I view, the intubator found that the stylet was too pliant to maintain its shape, and there was considerable delay while a thicker and stiffer stylet was obtained.

Most tracheal intubations were rated as "easy". For those that were not, the main problems consisted of awkwardness inserting the tracheal tube into the larynx, and difficulty advancing the tube into the trachea once the tip had passed between the vocal cords, despite good laryngeal views. These problems have also been reported with other videolaryngoscopes. ${ }^{1,2,10,12,13,32}$

We believe that two reasons account for these difficulties. First, during direct laryngoscopy, a straight line of sight is created by aligning oral, pharyngeal and laryngeal axes, allowing passage of the tracheal tube in a straight line. When using the McGrath ${ }^{\circledR}$ videolaryngoscope these axes are not aligned, and the tip of the tracheal tube must therefore pass around a relatively acute angle to enter the larynx. Less space is created for tube insertion when using the McGrath ${ }^{\circledR}$, as the pharyngeal tissues are not displaced as far anteriorly as during direct laryngoscopy. Mounting the tube onto a stylet and angling the distal tip upwards by $60-70^{\circ}$ at the proximal end of the cuff overcomes these problems, and allows easier insertion of the tube into the larynx. We have observed in manikin studies (unpublished data), using an earlier version of the $\mathrm{McGrath}{ }^{\circledR}$, that a stylet facilitates tracheal intubation. We used a stylet for intubation in 144 patients, and intubation was unsuccessful on two occasions when a stylet was not used initially. We believe that using a stylet and correctly shaping the tracheal tube is mandatory to assist tracheal intubation with the $\mathrm{McGrath}{ }^{\circledR}$, as with other videolaryngoscopes. ${ }^{3,5,10,12,13}$ The rigidity of the stylet also seems to be important - we have found that a thicker, more rigid stylet makes tracheal intubation easier.

The second problem we encountered was difficulty in advancing the tube into the trachea once the tip of the tube had passed the vocal cords. For the reasons described above, the tip of the tracheal tube can abut against the anterior tracheal wall at a relatively acute angle, preventing its advancement into the trachea. We observed that the tube could be advanced more easily when the stylet is withdrawn slightly, accompanied by withdrawal of the laryngoscope blade $1-2 \mathrm{~cm}$, and rotating the top of the blade handle caudally. We also observed that rotating the tracheal tube can be helpful. Similar solutions have been proposed by users of other videolaryngoscopes. ${ }^{1,33}$

The depth of anesthesia and degree of muscle relaxation can affect ease of laryngoscopy and tracheal intubation. We did not stipulate choice or dose of muscle relaxant given to any patient, and we did not formally assess neuromuscular blockade before laryngoscopy. All patients received standard intubating doses of muscle relaxant from the attending anesthesiologist; laryngoscopy was attempted after fasciculation ceased following suxamethonium, after $90 \mathrm{sec}$ if rocuronium 
was used, or $150 \mathrm{sec}$ if atracurium was given. We do not believe that inadequate neuromuscular blockade contributed to difficulty in laryngoscopy or insertion of the tracheal tube in any patient.

We acknowledge the limitations in drawing conclusions from a case series reported from a single centre. Patients were unselected, not enrolled consecutively, no control group was used, and measurements were not blinded. However, we collected data consistently, prospectively and according to a protocol designed before the case series began. This approach should reduce any potential bias, and as no patient was withdrawn from the case series, should mitigate against problems of data interpretation. Reports of experience from other centres would confirm if our observations were reproducible. Nevertheless, we believe that this case series provides useful initial clinical information related to the $\mathrm{McGrath}{ }^{\circledR}$ videolaryngoscope, while offering suggestions to facilitate tracheal intubation with this new airway device.

In conclusion, the compact, fully self-contained, and portable $\mathrm{McGrath}{ }^{\circledR}$ videolaryngoscope produces excellent laryngoscopic views in patients with normal airways, as well as patients with predictors of difficult intubation. Although advancing the endotracheal tube may be awkward, as with other videolaryngoscopes, routine use of an intubating stylet easily overcomes this difficulty. Randomized controlled trials are warranted to compare the utility of this device compared to other videolaryngoscopes and advanced airway devices in patients with normal and compromised airways.

\section{Acknowledgements}

The authors sincerely thank the anaesthetists and theatre staff who assisted in this evaluation.

\section{References}

1 Rai MR, Dering A, Verghese C. The Glidescope system: a clinical assessment of performance. Anaesthesia 2005; 60: 60-4.

2 Sun DA, Warriner CB, Parsons DG, Klein R, Umedaly HS, Moult M. The GlideScope VideoLaryngoscope: randomized clinical trial in 200 patients. Br J Anaesth 2005; 94: 381-4.

3 Cooper RM, Pacey JA, Bishop MJ, McCluskey SA. Early clinical experience with a new VideoLaryngoscope (GlideScope) in 728 patients. Can J Anesth 2005; 52: 191-8.

$4 \operatorname{Lim} \Upsilon$, Yeo $S W$. A comparison of the GlideScope with the Macintosh laryngoscope for tracheal intubation in patients with simulated difficult airway. Anaesth Intensive Care 2005; 33: 243-7.
5 Agro F, Barzoi G, Montecchia F. Tracheal intubation using a Macintosh laryngoscope or a GlideScope in 15 patients with cervical spine immobilization. $\mathrm{Br} \mathrm{J}$ Anaesth 2003; 90: 705-6.

6 Asai T, Murao K, Shingu K. Training method of applying pressure on the neck for laryngoscopy: use of a videolaryngoscope. Anaesthesia 2003; 58: 602-3.

7 Weiss M, Schwarz U, Dillier CM, Gerber AC. Teaching and supervising tracheal intubation in paediatric patients using VideoLaryngoscopy. Paediatr Anaesth 2001; 11: 343-8.

$8 \operatorname{Lim} \Upsilon$, $\operatorname{Lim}$ TJ, $\operatorname{Lin} E H$. Ease of intubation with the GlideScope or Macintosh laryngoscope by inexperienced operators in simulated difficult airways. Can J Anesth 2004; 51: 641-2.

$9 \operatorname{Lim}$ TJ, $\operatorname{Lim} \Upsilon$, Lin EH. Evaluation of ease of intubation with the GlideScope or Macintosh laryngoscope by anaesthetists in simulated easy and difficult laryngoscopy. Anaesthesia 2005; 60: 180-3.

10 Cooper RM. The GlideScope VideoLaryngoscope. Anaesthesia 2005; 60: 1042.

11 Cooper RM. Use of a new videolaryngoscope (GlideScope) in the management of a difficult airway. Can J Anesth 2003; 50: 611-3.

12 Cuchillo JV, Rodriguez MA. Considerations aimed at facilitating the use of the new GlideScope videolaryngoscope (Letter, reply). Can J Anesth 2005; 52: 661-2.

13 Doyle DJ. The GlideScope video laryngoscope (Letter). Anaesthesia 2005; 60: 414-5.

14 Doyle DJ. Miniaturizing the GlideScope video laryngoscope system: a new design for enhanced portability (Letter). Can J Anesth 2004; 51: 642-3.

15 Doyle DJ. Awake intubation using the GlideScope video laryngoscope: initial experience in four cases (Letter). Can J Anesth 2004; 51: 520-1.

16 Fairweather N. Nasal insertion of tube to aid in glidescope use. Anaesth Intensive Care 2005; 33: 823.

17 Gooden CK. Successful first time use of the portable GlideScope ${ }^{\circledR}$ VideoLaryngoscope in a patient with severe ankylosing spondylitis (Letter). Can J Anesth 2005; 52: 777-8.

18 Hernandez $A$ A, Wong $D H$. Using a Glidescope for intubation with a double lumen endotracheal tube (Letter). Can J Anesth 2005; 52: 658-9.

19 Supbornsug K, Osborn IP. Topicalization of the airway using the glidescope (Letter). Anesth Analg 2004; 99: 1263-4.

20 Trevisanuto D, Fornaro E, Verghese C. The GlideScope ${ }^{\circledR}$ VideoLaryngoscope: initial experience in five neonates (Letter). Can J Anesth 2006; 53: 423-4.

21 Turkstra TP, Craen RA, Pelz DM, Gelb AW. Cervical spine motion: a fluoroscopic comparison during intu- 
bation with lighted stylet, GlideScope, and Macintosh laryngoscope. Anesth Analg 2005; 101: 910-5.

22 Xue FS, Zhang GH, Li XY, et al. Comparison of haemodynamic responses to orotracheal intubation with GlideScope ${ }^{\circledR}$ videolaryngoscope and fibreoptic bronchoscope. Eur J Anaesthesiol 2006: 23: 522-6.

23 Kaplan MB, Hagberg CA, Ward DS, et al. Comparison of direct and video-assisted views of the larynx during routine intubation. J Clin Anesth 2006; 18: 357-62.

24 Asai T, Shingu K. Use of the VideoLaryngoscope (Letter). Anaesthesia 2004; 59: 513-4.

25 Thompson AC. A new video laryngoscope. Anaesthesia 2004; 59: 410.

26 Timmermann A, Russo S, Graf BM. Evaluation of the CTrach--an intubating LMA with integrated fibreoptic system. Br J Anaesth 2006; 96: 516-21.

27 Mallampati SR, Gatt SP, Gugino LD, et al. A clinical sign to predict difficult tracheal intubation: a prospective study. Can Anaesth Soc J 1985; 32: 429-34.

28 Cormack RS, Lehane J. Difficult tracheal intubation in obstetrics. Anaesthesia 1984; 39: 1105-11.

29 Rose DK, Cohen MM. The airway: problems and predictions in 18,500 patients. Can J Anaesth 1994; 4l(5Ptl): 372-83.

30 el-Ganzouri AR, McCarthy RJ, Tuman KJ, Tanck EN, Ivankovich $A D$. Preoperative airway assessment: predictive value of a multivariate risk index. Anesth Analg 1996; 82: 1197-204.

31 Shiga T, Wajima Z, Inoue T, Sakamoto A. Predicting difficult intubation in apparently normal patients: a meta-analysis of bedside screening test performance. Anesthesiology 2005; 103: 429-37.

32 Doyle DJ, Zura A, Ramachandran M. VideoLaryngoscopy in the management of the difficult airway (Letter, reply). Can J Anesth 2004; 51: 95-6.

33 Dupanovic M, Diachun CA, Isaacson SA, Layer D. Intubation with the GlideScope VideoLaryngoscope using the "gear stick technique" (Letter). Can J Anesth 2006; 53: 213-4. 